DOI https://doi.org/10.30929/2307-9770.2021.09.03.05

UDC 378:78]-042.3:159.944:[616.98:578.834.1]-036.2

\title{
Impact of higher music education on coping with stress during COVID-19
}

\author{
Nalyvaiko O.., Lykhoshvai K. \\ V. N. Karazin Kharkiv National University, Kharkiv, Ukraine
}

Received: $24.08 .2021 \quad$ Accepted: 24.09 .2021

\begin{abstract}
The article is dedicated to the study if students with special musical education have any benefits of stress coping over students of other specialties during the pandemic. The main purpose is to study the attitude of student musicians to overcome stressful situations caused by COVID-19 in the learning process. Research objectives include: current state of music education in the context of forced quarantine distance learning; the impact of forced quarantine distance learning on stress among students of music and non-music specialties; the analysis of stress coping skills and the impact of music education on them; recommendations for improving the psychological and pedagogical interaction of the participants in the educational process. The study involved 160 respondents, 80 of them are music students and 80 students of other specialties that do not belong to the study of musical art. To collect information and data, the study participants were asked to fill out a Google form. The results of the study show that online learning is very time-consuming and that losing a satisfactory work-life balance is stressful. But students became more organized in managing their activities. Internet platforms have proven useful for sharing materials, communicating, sharing information and content, and keeping track of all work done. Thus, there is a tendency towards easier tolerance of stress by musicians, although our study showed that with a slight margin of $80.6 \%$, people without musical education consider themselves happier by $82 \%$. This is also confirmed by the fact that nonmusicians are more optimistic about their future according to the results obtained on the Beck's Hopelessness Scale, where 2 units are for musicians and 1 for non-musicians. These results indicate that hopelessness has not been identified and students are optimistic about their future. In the context of stress coping recommendations for students are provided. In conclusion, based on the information gained and own experience there is a variety of ways to obtain benefits from both online and offline learning forms for both musicians and non-musicians.
\end{abstract}

Key words: stress, forced distance learning, COVID-19, education, higher education, coping with stress.

\section{Вплив вищої музичної освіти на вміння впоратися зі стресом під час COVID-19}

\author{
Наливайко О. О., Лихошвай К. Ю. \\ Харківський національний університет імені В.Н. Каразіна, Харків, Україна
}

\begin{abstract}
Анотація. Стаття присвячена дослідженню того, чи є у студентів зі спеціальною музичною освітою переваги в подоланні стресу в порівнянні зі студентами інших спеціальностей в період пандемії. Основна мета - вивчення ставлення студентів-музикантів до подолання стресових ситуацій, викликаних COVID-19, в процесі навчання. Завдання дослідження: сучасний стан музичної освіти в контексті вимушеного дистанційного навчання; вплив вимушеного дистанційного навчання на стрес у студентів музичних і не музичних спеціальностей; аналіз навичок подолання стресу і впливу музичної освіти на них; рекомендації щодо вдосконалення психологопедагогічної взаємодії учасників освітнього процесу. У дослідженні взяли участь 160 респондентів, 80 з них студенти музики та 80 студентів інших спеціальностей, які не належать до вивчення музичного мистецтва. Для збору інфрормації та даних учасників дослідження попросили заповнити Google форму. Результати дослідження показують, що онлайн-навчання вимагає дуже багато часу і що втрата задовільного балансу між роботою та особистим життям викликає стрес. Але студенти стали більш організованими в управлінні своєю діяльністю. Інтернет-платформи виявилися корисними для обміну матеріалами, спілкування, обміну інформацією і контентом, а також для відстеження всієї виконаної роботи. Таким чином, простежується
\end{abstract}

Corresponding Author: Oleksii Nalyvaiko, Tel. +380639586169 .E-mail: nalyvaiko@karazin.ua V. N. Karazin Kharkiv National University, Maidan Svobody, 6, Kharkiv, Ukraine, 61022.

Bidnoвidальний автор: Наливайко Олексій Олексійович, Тел. 0639586169. E-mail: nalyvaiko@karazin.ua Харківський національний університет імені В.Н. Каразіна, Майдан Свободи, 6, Харків, 61022. 
тенденція до більш легкої переносимості стресу музикантами, хоча наше дослідження показало, що 3 невеликим відривом в 80,6\% люди без музичної освіти вважають себе щасливішими на 82\%. Це також підтверджується тим фактом, що люди, які не є музикантами, більш оптимістично дивляться на своє майбутнє згідно з результатами, отриманими за шкалою безнадійності Бека, де 2 одиниці призначені для музикантів, а 1 - для не музикантів. Ці результати показують, що безнадійність не визначена, і студенти з оптимізмом дивляться в майбутнє. В контексті подолання стресу для студентів надані рекомендації. У підсумок слід зазначити, що на основі отриманої інформації і власного досвіду існує безліч способів отримати користь від онлайн- та офлайн- форм навчання як для музикантів, так і для не музикантів.

Ключові слова: стрес, вимушене дистанційне навчання, COVID-19, музична освіта, вища освіта, подолання стресу.

\title{
Влияние высшего музыкального образования на умение справиться со стрессом во время COVID-19
}

\author{
Наливайко А. А., Лихошвай К. Ю. \\ Харьковский национальный университет имени В. Н. Каразина, Харьков, Украина
}

\begin{abstract}
Аннотация. Статья посвящена исследованию того, есть ли у студентов со специальным музыкальным образованием преимущества в преодолении стресса по сравнению со студентами других специальностей в период пандемии. Основная цель - изучение отношения студентов-музыкантов к преодолению стрессовых ситуаций, вызванных COVID-19, в процессе обучения. Задачи исследования: современное состояние музыкального образования в контексте вынужденного дистанционного обучения; влияние вынужденного дистанционного обучения на стресс у студентов музыкальных и не музыкальных специальностей; анализ навыков преодоления стресса и влияния на них музыкального образования; рекомендации по совершенствованию психолого-педагогического взаимодействия участников образовательного процесса. В исследовании приняли участие 160 респондентов, из них 80 студентов музыкантов и 80 студентов других специальностей, не относящихся к изучению музыкального искусства. Для сбора информации и данных участников исследования попросили заполнить Google форму. Результаты исследования показывают, что онлайн-обучение требует очень много времени и что потеря удовлетворительного баланса между работой и личной жизнью вызывает стресс. Но студенты стали более организованными в управлении своей деятельностью. Интернет-платформы оказались полезными для обмена материалами, общения, обмена информацией и контентом, а также для отслеживания всей проделанной работы. Таким образом, прослеживается тенденция к более легкой переносимости стресса музыкантами, хотя наше исследование показало, что с небольшим отрывом в 80,6\% люди без музыкального образования считают себя счастливее на $82 \%$. Это также подтверждается тем фрактом, что люди, не являющиеся музыкантами, более оптимистично смотрят на свое будущее согласно результатам, полученным по шкале безнадежности Бека, где 2 единицы предназначены для музыкантов, а 1 - для не музыкантов. Эти результаты показывают, что безнадежность не выявлена, и студенты с оптимизмом смотрят в будущее. В контексте преодоления стресса для студентов даны рекомендации. В заключение следует отметить, что на основе полученной информации и собственного опыта существует множество способов получить пользу от онлайн- и офрлайн-форм обучения как для музыкантов, так и для не музыкантов.
\end{abstract}

Ключевые слова: стресс, вынужденное дистанционное обучение, COVID-19, образование, высшее образование, преодоления стресса.

\section{Introduction}

As you know, our world had a chance to face a global problem in the form of COVID-19 [1; 17], which greatly influenced the social order. Higher education institutions and students are no exception. In a previous article, we examined the impact of distance and blended learning on the quality of education of psychology students [11]. According to the results of the study, it became clear that distance learning is more likely to have a detrimental effect on the quality of education, and also makes students experience severe stress during the learning process. We assume that students of other specialties, and not just psychologists, experience severe stress. However, everyone finds their own ways to cope with this phenomenon. Someone does better, and someone worse. As a result, the question arose about how exactly students of other specialties, in particular musicians, cope with stress, and do they do better than other students? A number of researchers noted [18; $21 ; 22 ; 24]$ that music affects the human brain, including the quality and ability to cope with stress. Consequently, it can be assumed that music students in higher education who have constant contact with 
music cope better with stress compared to students in other specialties. Unlike ordinary people who listen to music, university students devote a lot of time and effort to this process.

An important factor that influenced the choice of the research topic was the introduction of forced distance learning at all levels of the educational system of Ukraine [12]. The suddenness of the introduction of distance learning throughout the education system has led to some confusion and imbalance in the educational process. Especially these processes influenced such fields of education as: medicine, natural sciences and creative and musical directions. Mastering any musical instrument presupposes numerous practical lessons and exercises, and in the conditions of forced distance learning, these procedures greatly lost in the quality of performance in conditions of the uneven potential and capabilities of digital means of communication that are available to participants in the educational process (students and teachers). This state of affairs leads to stressful situations and a deterioration in the effectiveness of training.

The digitalization of public relations in recent decades has reached unprecedented heights and education is no exception [13], but the saturation with digital means of communication and gadgets does not mean that people can use them on an ongoing basis without harm to their health, both physical and psychological. The issues of dealing with stress in a pandemic occupy one of the leading places in the context of the normalization of public life.

Thornton L. [23] in his work "Music Education at a Distance" notes that music and learning came into disarray in the conditions of forced distance learning, but the participants in the educational process, student musicians and teachers responded to this with a three-pronged approach: creativity, cohesion, and feedback. Interaction under stressful conditions requires a special approach in the learning process: compassion, patience and attentiveness to the needs of students. In these conditions, teachers became the conductors of humanity and showed that we must think about each person who needs care. Forced distance learning encouraged music teachers to learn more about students and on this knowledge, adapt and provide support [23].

Thornton L. [23] notes that in our current state, music teachers are also trying to understand what distance learning is. Music teachers continue their meetings and classes over the Internet, feeling tired at the end of the day, tired of constantly staring at the screen, tired of interpreting unfamiliar social cues. There is currently no technological way to create music together in real time in remote locations. Offline learning creates a sense of engagement, which so positively affects community in the creative environment, symbiotic give-and-take in conversation, discussion or musical interaction is also important [23].

Any supposed turn towards online experiences in music education is not new; digital technology and online learning have been an important part of music education for several decades. What is perhaps new during the global pandemic crisis is that music education must operate primarily in the digital / online space, and this necessary "turnaround" has led to significant disruptions in the practice of many music teachers [6].

Drawing on the experiences of conservatory students during the crisis, Schiavio A., Maes, P.-J., \& Van der Schyff $D$. article [19] highlights a number of challenges as well as the benefits of turning to online music education, not least the pressure it puts on teachers to quickly adapt to music education using technology to maintain high pedagogical standards. Their article illustrates very clearly the difficulties of teaching during a pandemic, with student stories highlighting how their musical development may have been disrupted by the pandemic, and how to develop strategies and attitudes to overcome such setbacks - especially with their peers. According to Schiavio A., Maes P.-J., \& Van der Schyff D. [19], "the need for novelty and research [in response to the crisis] has led to the emergence of new forms of communication between students, highlighting the connection between creativity and social bonds." The implications for teachers are very clear to continue to be integral to the continuous development of students, they must be able to smoothly and effectively adapt pedagogical approaches to unfamiliar and destructive circumstances, and this also requires educational institutions to mobilize the necessary resources and train their staff so that they can respond most efficiently [19].

Cheng L. \& Lam C. Y. [5] provide a detailed analysis of the psychological impact of the pandemic on music teachers in Hong Kong, using a multi-strategic approach to understand this impact in both quantitative and qualitative terms. Their work points to an important feature of resilience among educators, perhaps unsurprisingly that less experienced teachers, as well as those who only taught music, were more susceptible to the stresses associated with adapting to emergency distance learning. 
Cheng L. \& Lam C. [5] point to a number of the most common stressors:

- excessive parental involvement;

- inconsistency in the management system of the educational institution;

- technological problems;

- low digital skills of participants in the educational process.

Summing up, the authors point out that the presence of many stress factors can have a destabilizing effect on the pedagogical process and its participants [5].

An important factor that actualizes our scientific searches is the presence of a complex of problems associated with the introduction of digital online technologies [4] in the process of teaching musicians, this is not only stress, but also the problems that come with it, this is the availability of the necessary technical support (video and especially sound) and the search for time for educational and consultative interaction between the participants in the educational process, adaptation to new forms of control in the context of home education. A number of these questions are raised in his study "The digital 'turn' in music education (editorial)" by David A. Camlin \& Tania Lisboa [6]. Revealing the complex of problems that have arisen in the conditions of the introduction of quarantine and distance learning, they introduce a new term to designate precisely unplanned distance interaction in the process of studying musical art. David A. Camlin \& Tania Lisboa [6] introduce the concept of "emergency distance learning" that many music educators have encountered in 2020, point to a number of features when there is a sudden and unexpected need to adapt to a situation of social isolation and when some form of online teaching has become the only way to support any kind of music education practice. David A. Camlin \& Tania Lisboa [6] highlight one of the main problems inherent in "emergency distance learning" in music education as the need for modern studio equipment up to home computer systems, including laptops and headsets, such innovations have introduced requirements that were not there before. and this led to stress for the participants in the educational process.

Purpose of the study. To study the attitude of student musicians to overcoming stressful situations caused by COVID-19 in the learning process.

Research objectives:

- Show the current state of music education in the context of forced distance learning;

- Describe the impact of forced distance learning on stress among students of music and non-music specialties;

- Analyze stress coping skills and the impact of music education on them;

- On the basis of the data obtained, give recommendations for improving the psychological and pedagogical interaction of the participants in the educational process.

\section{Materials and Methods}

The study used a set of methods to collect and analyze the required information and data. These were theoretical methods of analysis and synthesis of information, a method of systematization. Also, the authors used practical methods. The study involved 160 respondents, 80 of them are music students and 80 students of other specialties that do not belong to the study of musical art. To collect information and data, the study participants were asked to fill out a google form, it is important to note that the forms were slightly different for students musicians and non-musicians, so students musicians were asked to answer the question "How often do you listen to music outside of class?" And for non-musicians "How often do you listen to music in general? " The form for musicians included 12 general and specific questions to determine their attitude to coping with the stress caused by the COVID-19 pandemic and forced distance learning [12]. The Google form for nonmusicians consisted of 12 general and specific questions. The Google form also included links to the Oxford Happiness Inventory [16], as well as the Beck's Hopelessness Scale [2], a clinical test method that measures the severity of negative attitudes towards the subjective future of adults and adolescents. It can be used as an indirect indicator of suicidal risk for patients with depression [2]. 
- Gender? (Female/male/other)

\section{Google form set of questions for musicians}

- Age? (17-19/20-22/23-25)

- Education? (music college/conservatory)

- Your specialty?

- How often do you listen to music outside the classes? (always/often/sometimes/rarely)

- Does music help you to cope the stress? (yes/sometimes/rarely/no)

- How do you feel, if you stay without music for a long time? (very bad/bad/okay/good/excellent)

- How does distance learning affect the quality of your education comparing to classroom learning? (I don't understand anything/ It's hard to figure out, but possible/ Nothing has changed/ It is easier and more interesting to learn/ I'm doing good, my grades are better)

- How did distance education affect you? (I experience lots of stress/ I experience stress/ Nothing really changed/ Positively/ Very positively)

- What difficulties do you have during distance education?

- Did you listen to music during quarantine more often than before? (yes/no)

- How do you usually cope the stress?

- Gender? (Female/male/other)

\section{Google form set of questions for non-musicians}

- $\quad$ Age? (17-19/20-22/23-25)

- Education? (bachelor degree/ master's degree)

- Your specialty?

- How often do you listen to music? (always/often/sometimes/rarely)

- Does music help you to cope the stress? (yes/sometimes/rarely/no)

- How do you feel, if you stay without music for a long time? (very bad/bad/okay/good/excellent)

- How does distance learning affect the quality of your education comparing to classroom learning? (I don't understand anything/ It's hard to figure out, but possible/ Nothing has changed/ It is easier and more interesting to learn/ I'm doing good, my grades are better)

- How did distance education affect you? (I experience lots of stress/ I experience stress/ Nothing really changed/ Positively/ Very positively)

- What difficulties do you have during distance education?

- Did you listen to music during quarantine more often than before? (yes/no)

- How do you usually cope the stress?

\section{Results}

Research by a number of scientists $[7 ; 17 ; 24]$ shows that stress is one of the most acute problems of modern society, especially this problem has acquired in the context of quarantine restrictions caused by COVID-19. In the 21st, humanity has not yet faced such a global challenge as global quarantine restrictions, which is further aggravated by the global crisis and the de-globalization of the world community and economy [9].

In these conditions of colossal stress of psychological and physical forces for everyone, a particularly vulnerable category of citizens are students who study creative specialties. This category also includes future musicians. Uncertainty about the future, coupled with learning in an unfamiliar and often hostile environment, leaves music students under constant stress. To this can be added the insufficient level of development of music education in Ukraine, which affects the quality of training of future musicians [20].

It is clear that the pandemic crisis has significantly disrupted the natural course of music education and also triggered important conceptual and epistemological shifts both in theory and practice in music education. Practitioners and theorists of music education and related fields ponder how best to adapt to these shifts. Valuable observations are expressed by Cheng L. \& Lam C. [5] that "music teachers realize that they need to 
turn from instructors to facilitators of student learning" in response to the crisis, which shows that the learning process will never be the same.

Since the online world contains many more resources than just the teacher's knowledge, rethinking the foundations of the organization of the educational process and the role of the teacher becomes the main task of modern post-covid education, understanding the new role of the teacher in this difficult situation becomes a matter of significant "pedagogical necessity" [8].

Inadequacy in the provision of resources, and in the support of teachers themselves, can inevitably lead to a deterioration in the effectiveness of training future musicians, emphasizing the importance of technological resources, training and support, allowing teachers to provide students with the best opportunities to gain knowledge and experience in the art of music [6]. It is important to note that clear working conditions create a favorable atmosphere in educational interaction, which can also positively affect the reduction of stressful situations among participants in the educational process.

The development of modern music education is closely related to the inclusion of various forms of work with students, contributing to the renewal of the quality of the content of courses, both theoretical and specialized. For better educational activities and increasing interest in learning, it is necessary to constantly monitor the activities of participants in the educational process.

The introduction of various forms of learning and creativity will allow students to develop critical thinking and will contribute to the awareness of the relevance of the knowledge gained and their diversity, and this, in turn, will help in reducing the amount of educational stress. The aim of modern higher education institutions in the field of music training should be to provide exclusive knowledge, information and opportunities that would not be possible without training in this particular institution.

This can be achieved through the inclusion in the daily work of students and teachers of such forms of organization of training as:

- master classes by recognized masters of the music workshop;

- online viewing of performances and concerts of the world's leading theaters and groups in specially equipped rooms (professional sound and picture quality for studying the movements of musicians, etc.);

- hours of free (independent) collective creativity [15].

As noted by the team of scientists Ostapenko L., Narozhna N., \& Sinelnikova V. [15], the development of music education is also impossible without the introduction of the latest technologies associated with the creation, recording and modification of music using appropriate digital programs. The study of this software is carried out in art education institutions, but requires more thorough study and constant updating of the technical component. After all, the use of the appropriate software allows not only to create musical samples, but also to study the already existing audio content [10; 15].

We studied the current situation related to the development of music education and its connection with digital teaching tools, we will proceed to the analysis of our own data obtained as a result of collecting complex information about the stated problem of stress resistance

Based on the results obtained from our own questionnaire, the following observations can be distinguished:

1. The study involved 80 musicians and 80 non-musicians. In both groups, there were $1: 4$ men and $3: 4$ women with a slight difference. Consequently, the results are dominated by how female students cope with stress and what difficulties in distance learning face (Tab. 1).

Table 1. Gender

\begin{tabular}{|c|c|c|c|}
\cline { 2 - 4 } \multicolumn{1}{c|}{ Musicians } & Gender & Frequency & Percentage \\
\cline { 2 - 4 } & Male & 26 & 32,5 \\
\cline { 2 - 4 } & Female & 54 & 67,5 \\
\cline { 2 - 4 } & Total & 80 & 100 \\
\hline \multirow{3}{*}{ Non-musicians } & Male & 23 & 28,7 \\
\cline { 2 - 4 } & Female & 57 & 71,3 \\
\cline { 2 - 4 } & Total & 80 & 100 \\
\hline
\end{tabular}


2. The age of the subjects varies from 17 to 25 years old and it is worth noting that in the group of musicians there are more students aged 20-22, which allows them to more clearly feel the difference between classroom and distance learning. While in the group of non-musicians, more students aged 17-19 took part in the survey, who did not yet have the opportunity to fully try classroom teaching, respectively, their experience is due only to distance learning (Tab. 2).

Table 2. Age

\begin{tabular}{|c|c|c|c|}
\cline { 2 - 4 } \multicolumn{1}{c|}{} & Age & Frequency & Percentage \\
\hline \multirow{3}{*}{ Musicians } & $17-19$ & 12 & 15 \\
\cline { 2 - 4 } & $20-22$ & 47 & 58,8 \\
\cline { 2 - 4 } & $23-25$ & 21 & 26,2 \\
\hline \multirow{3}{*}{ Non-musicians } & $17-19$ & 48 & 60 \\
\cline { 2 - 4 } & $20-22$ & 28 & 35 \\
\cline { 2 - 4 } & $23-25$ & 4 & 5 \\
\hline
\end{tabular}

3. Music students enter the music school after the ninth grade, so they enter the conservatory at a fairly early age, which explains the superiority of this level of education in the sample group. Unlike students of other specialties, most of whom receive a bachelor's degree Tab. 3 .

Table 3. Education

\begin{tabular}{|c|c|c|c|}
\cline { 2 - 4 } \multicolumn{1}{c|}{} & Education & Frequency & Percentage \\
\hline \multirow{2}{*}{ Musicians } & Music college & 21 & 26,3 \\
\cline { 2 - 4 } & Conservatory & 59 & 73,8 \\
\hline \multirow{2}{*}{ Non-musicians } & Bachelor degree & 74 & 92,5 \\
\cline { 2 - 4 } & Master's degree & 6 & 7,5 \\
\hline
\end{tabular}

4. Among musicians, students of 11 different specialties took part in the study. The diversity of students from other faculties reaches a value of 25 .

5. Students of both groups quite often listen to music outside the classroom, and only with a small margin, students musicians listen to it on an ongoing basis (Tab. 4).

Table 4. The influence of music on stress

\begin{tabular}{|c|c|c|c|}
\cline { 2 - 4 } \multicolumn{1}{c|}{} & Options & Frequency & Percentage \\
\hline \multirow{4}{*}{ Musicians } & Yes & 50 & 62,5 \\
\cline { 2 - 4 } & Sometimes & 22 & 27,5 \\
\cline { 2 - 4 } & Rarely & 6 & 7,5 \\
\cline { 2 - 4 } & No & 2 & 2,5 \\
\hline \multirow{4}{*}{ Non-musicians } & Yes & 46 & 57,5 \\
\cline { 2 - 4 } & Sometimes & 27 & 71,3 \\
\cline { 2 - 4 } & Rarely & 4 & 5 \\
\cline { 2 - 4 } & No & 3 & 3.7 \\
\hline
\end{tabular}


6. When asked whether music helps to cope with stress, more than half of the subjects gave a positive answer. However, the results did not differ significantly from group to group.

7. Surprisingly, $43.8 \%$ of musicians feel bad after being without music for a long time, and at the same time, most of the students of other specialties feel normal. This phenomenon may be facilitated by the fact that music is an integral part of the life and profession of music students, to which they devote many years, so they definitely experience more stress being without music for a long time than other students of Tab. 5 .

Table 5. The state without music

\begin{tabular}{|c|c|c|c|}
\cline { 2 - 4 } \multicolumn{1}{c|}{} & Options & Frequency & Percentage \\
\hline \multirow{4}{*}{ Musicians } & Very bad & 5 & 6,3 \\
\cline { 2 - 4 } & Bad & 35 & 43,8 \\
\cline { 2 - 4 } & Okay & 35 & 43,8 \\
\cline { 2 - 4 } & Fine & 3 & 3,7 \\
\cline { 2 - 4 } & Excellent & 2 & 2,5 \\
\hline \multirow{4}{*}{ Non-musicians } & Very bad & 3 & 3,8 \\
\cline { 2 - 4 } & Bad & 23 & 28,7 \\
\cline { 2 - 4 } & Okay & 49 & 61,3 \\
\cline { 2 - 4 } & Fine & 3 & 3,7 \\
\cline { 2 - 4 } & Excellent & 2 & 2,5 \\
\hline
\end{tabular}

8. The overwhelming number of students claims that with the onset of distance learning, the learning process is more complicated, but you can figure it out. Also, for some students, on the contrary, it became easier and more interesting to study.

9. Half of the students in non-music majors did not feel the change with the advent of distance learning. It can be assumed that such indicators are based on the fact that students of 17-19 years old have not yet had a chance to attend classroom classes. From the side of student musicians, the situation is slightly different. Some of them do not feel changes, and some are under stress (Tab. 6).

Table 6. The affect of distance learning on students

\begin{tabular}{|c|c|c|c|}
\cline { 2 - 4 } \multicolumn{1}{c|}{} & Options & Frequency & Percentage \\
\hline \multirow{4}{*}{ Musicians } & $\begin{array}{c}\text { I experience lots of } \\
\text { stress }\end{array}$ & 9 & 11,3 \\
\cline { 2 - 4 } & I experience stress & 29 & 36,3 \\
\cline { 2 - 4 } & $\begin{array}{c}\text { Nothing really } \\
\text { changed }\end{array}$ & 27 & 33,8 \\
\cline { 2 - 4 } & Positively & 11 & 13,7 \\
\cline { 2 - 4 } & Very positively & 4 & 5 \\
\hline \multirow{4}{*}{\begin{tabular}{c} 
Non- \\
\cline { 2 - 4 }
\end{tabular}} & $\begin{array}{c}\text { I experience lots of } \\
\text { stress }\end{array}$ & 4 & 5 \\
\cline { 2 - 4 } & I experience stress & 19 & 23,8 \\
\cline { 2 - 4 } & $\begin{array}{c}\text { Nothing really } \\
\text { changed }\end{array}$ & 40 & 50 \\
\cline { 2 - 4 } & Positively & 7 & 8,8 \\
\cline { 2 - 4 } & Very positively & 10 & 12,5 \\
\hline
\end{tabular}


10. Despite the fact that both groups of students experience more or less stress in connection with distance learning, the main sources of stress differ (Tab. 7). For example, the biggest challenge for students in other majors is self-discipline. Some subjects describe the problem as follows:

- "Self-discipline. It's hard to force yourself to sit down and learn the subject";

- "Forcing yourself to do something";

- "Procrastination".

However, musicians are more concerned about the adaptation of the educational process to the online space. Some of their comments:

- "It is not possible to work with a teacher majoring in online"; held":

- $\quad$ The problem is to understand and understand the programs and platforms where classes are

- "Sometimes the topic is not clear and the teacher cannot explain it so well online".

Table 7. The main difficulties

\begin{tabular}{|c|c|c|c|}
\hline & Options & Frequency & Percentage \\
\hline \multirow{6}{*}{ Musicians } & $\begin{array}{c}\text { Adaption of classes } \\
\text { to online space }\end{array}$ & 22 & 17,8 \\
\hline & The lack of practice & 21 & 16,8 \\
\hline & $\begin{array}{c}\text { Contact with the } \\
\text { teacher }\end{array}$ & 16 & 12,8 \\
\hline & $\begin{array}{c}\text { Troubles with } \\
\text { understanding and } \\
\text { learning } \\
\text { information }\end{array}$ & 16 & 12,8 \\
\hline & $\begin{array}{c}\text { Live } \\
\text { communication }\end{array}$ & 11 & 8,8 \\
\hline & Self-discipline & 22 & 17,8 \\
\hline \multirow{5}{*}{$\begin{array}{l}\text { Non- } \\
\text { musicians }\end{array}$} & Internet connection & 17 & 13,6 \\
\hline & $\begin{array}{c}\text { Contact with the } \\
\text { teacher }\end{array}$ & 12 & 9,6 \\
\hline & $\begin{array}{c}\text { Live } \\
\text { communication }\end{array}$ & 11 & 8,8 \\
\hline & $\begin{array}{c}\text { Troubles with } \\
\text { understanding and } \\
\text { learning } \\
\text { information }\end{array}$ & 11 & 8,8 \\
\hline & & & \\
\hline
\end{tabular}

11. An interesting result of the observation was that almost half of the students of other specialties began to listen to music during the quarantine more than before. But for musicians, quarantine did not become a reason to listen to music more often (Tab. 8). 
Table 8. The frequency of listening to music during quarantine

\begin{tabular}{|c|c|c|c|}
\cline { 2 - 4 } \multicolumn{1}{c|}{} & Options & Frequency & Percentage \\
\hline \multirow{2}{*}{ Musicians } & Yes & 19 & 23,8 \\
\cline { 2 - 4 } & No & 61 & 76,3 \\
\hline \multirow{2}{*}{ Non-musicians } & Yes & 38 & 47,5 \\
\cline { 2 - 4 } & No & 42 & 52,2 \\
\hline
\end{tabular}

12. When asked about ways to cope with stress, the groups' responses did not differ significantly, with listening to music ranked first, which is surprisingly a third more musicians who use this method. As for the rest, hobbies, distracted pursuits, and for musicians playing an instrument have become the main sources of stress coping. Tab. 9.

Table 9. Ways of stress coping

\begin{tabular}{|c|c|c|c|}
\hline & Options & Frequency & Percentage \\
\hline \multirow{5}{*}{ Musicians } & Listening to music & 21 & 16,8 \\
\hline & Hobby & 13 & 10,4 \\
\hline & $\begin{array}{l}\text { Playing the } \\
\text { instrument }\end{array}$ & 11 & 8,8 \\
\hline & Get distracted & 10 & 8 \\
\hline & $\begin{array}{c}\text { Friends/family } \\
\text { support }\end{array}$ & 10 & 8 \\
\hline \multirow{5}{*}{ Non-musicians } & Listening to music & 32 & 25,6 \\
\hline & Get distracted & 18 & 14,4 \\
\hline & Food & 17 & 13,6 \\
\hline & Movies/ shows & 16 & 12,8 \\
\hline & Walks & 14 & 11,2 \\
\hline
\end{tabular}

When it comes to the results of tests on the level of happiness, the difference between the two groups is minimal. Musicians are only $2 \%$ inferior to students of other specialties, showing the result of $80 \%$. Beck's test for the level of hopelessness also showed positive results, which suggests that the subjects of both groups have hopes and have a positive outlook on their future.

\section{Discussion}

As we can see, an increase of stress in unusual conditions of quarantine restrictions is a significant factor that affects human life in all its manifestations.

The recent global emergency caused by COVID-19 has forced many music teachers to use distance learning methods in their practice. For example, an article by Biasutti, M., Antonini Philippe, R., \& Schiavio, A. [3] explores the practices and strategies used by conservatory-level music teachers to deliver online lessons across Europe and the United States. Scientists collected data for their research through interviews covering aspects such as curriculum, lesson execution, assessment, exam organization, and time management skills. The respondents provided detailed descriptions of their experience in teaching music theory and practical lessons. Participants discussed their ability to manage technology and used skills such as flexibility, problem solving and creativity in planning their curriculum and using various distance learning tools. They redefined instructional activities, and online learning strategies and methods were related to playing musical instruments. Respondents claimed that online learning is very time-consuming (for example, planning events, preparing 
materials, and exploring new possibilities of technical tools) and that losing a satisfactory work-life balance is stressful. But in contrast to the stress, they became more organized in managing their activities. Internet platforms have proven useful for sharing materials, communicating, sharing information and content, and keeping track of all work done. Participants learned to systematically use video content for modeling and teaching [3].

Study by Payne P., Lewis W., \& McCaskill F. [18]. shows the current state of mental health of music students in the US educational space. According to the results shown in the study [18], the specialized music education groups are very busy, gaining an average of 16.5 credit hours (excluding courses with zero credit) and rehearsing 9.75 hours a week; most of them also work an average of 13 to 15 hours a week. Participants reported increased stress levels, with $57 \%$ moderate to severe depression and over $70 \%$ moderate to severe anxiety.

According to the group of scientists De Witte, M, Spruit A., Van Hooren S., Moonen X. \& Stams G.-J. [7] Music intervention has been used to reduce stress in a variety of conditions because of the positive effects of listening to music on both physiological arousal (eg, heart rate, blood pressure, and hormonal levels) and psychological stress (eg, anxiety and nervousness). The researchers conducted two multilevel meta-analyzes, containing 327 effect sizes and 9617 participants, to assess the strength of the effect of the musical intervention on physiological and psychological stress outcomes and to test for potential moderators of the intervention's effects. The results showed that musical intervention in general had a significant effect on stress reduction in terms of both physiological $(d=0.380)$ and psychological $(d=0.545)$ outcomes. In addition, moderated analysis showed that the type of outcome assessment mitigated the effect of musical intervention on stress-related outcomes. A greater effect was found on heart rate $(d=0.456)$ compared to blood pressure $(d=0.343)$ and hormone levels $(d=0.349)[7]$.

In the context of the stated problem, it would be appropriate to say that any "turn" to online music education caused by the pandemic should not contribute to the useless analysis of online and offline experiences in its various manifestations. Experience has shown that there are clear advantages of music education at both online and offline, and both areas need to be considered when developing music curriculum and how these curriculum will be implemented "in the field" of uncertainty and new challenges [6] ... It is already becoming obvious that the pandemic has forever changed the existing approaches to training not only musicians, but specialists in other specialties. In addition, new programs for preparing students need to include a binary approach of both online and offline learning, and even more important is the adaptation of students to the existing conditions for acquiring knowledge and skills inherent in these programs on the basis of increased stress from changing forms of education.

The article by Nogaj A. [14] provides interesting data on the psychosocial functioning of students with creative abilities. More than 350 students of music, art and general education schools, aged 16 to 19 , took part in the study. The hypothesis of the study was that the diversity of situations faced by students in different types of schools can create differences in their socio-emotional functioning, with particular attention to characteristics such as emotional intelligence and coping strategies. The variables associated with emotional intelligence were acceptance, empathy, control, and understanding, while the variables associated with coping strategies were task orientation, emotion, and avoidance. The results of the study showed that music students were significantly different from art students in terms of emotional intelligence in overall performance and on the scale of acceptance; they are more aware of the positive and negative emotions they experience, express their emotions more easily, and can effectively use their knowledge of the emotions they experience. Moreover, in stressful situations, music students are much more likely to demonstrate task-oriented strategies for overcoming difficulties and are much less likely to participate in substitute activities than art students [14]. Thus, there is a tendency towards easier tolerance of stress by student musicians in the above study, although our study showed that with a slight margin of $80.6 \%$, people without musical education consider themselves happier by $82 \%$. This is also confirmed by the fact that non-musicians are more optimistic about their future according to the results obtained on the Beck's Hopelessness Scale, where 2 units are for musicians and 1 for non-musicians. These results indicate that hopelessness has not been identified and students are optimistic about their future. 


\section{Conclusions}

Based on the results obtained, the following recommendations for students can be distinguished: during distance learning, difficulties can really arise, and in particular those that are difficult to influence, such as the Internet connection, the adaptation of the educational process to the online space or self-discipline. However, during times when you cannot deal with the amount of stress on your own, try to surround yourself with support from those sources where you can get it, because coping with difficulties alone is not an easy task. And also find ways to accommodate your feelings associated with stressful situations. With a high quality selfcare and mental health care, you can a significantly increase chances of coping stress without problems.

\section{References}

1. Bardus, I., Herasymenko, Y., Nalyvaiko, O., Rozumna, T., Vaseiko, Y., \& Pozdniakova, V. (2021). Organization of Foreign Languages Blended Learning in COVID-19 Conditions by Means of Mobile Applications. Revista Romaneasca Pentru Educatie Multidimensionala, 13(2), 268-287. https://doi.org/10.18662/rrem/13.2/421

2. Beck A.T, Weissman A., Lester D., Trexler L. (1974). Measurement of pessimism: The hopelessness scale // Journal of Consulting and Clinical Psychology, 42 (6), 861 -865.

3. Biasutti, M., Antonini Philippe, R., \& Schiavio, A. (2021). Assessing teachers' perspectives on giving music lessons remotely during the COVID-19 lockdown period. Musicae Scientiae. https://doi.org/10.1177/1029864921996033

4. Cayari, C. (2018). Connecting Music Education and Virtual Performance Practices from YouTube. Music Education Research, 20 (3), 360-376. doi:10.1080/14613808.2017.1383374).

5. Cheng L. \& Lam C. Y. (2021) The worst is yet to come: the psychological impact of COVID-19 on Hong Kong music teachers, Music Education Research, 23(2), 211-224, DOI: 10.1080/14613808.2021.1906215

6. David A. Camlin \& Tania Lisboa (2021) The digital 'turn' in music education (editorial). Music Education Research, 23(2), 129-138, DOI: 10.1080/14613808.2021.1908792.

7. De Witte, M, Spruit A., Van Hooren S., Moonen X. \& Stams G.-J. (2020) Effects of music interventions on stress-related outcomes: a systematic review and two meta-analyses. Health Psychology Review, 14(2), 294-324, DOI: 10.1080/17437199.2019.1627897

8. Huhtinen-Hildén and Pitt 2018.Huhtinen-Hildén, L., and J. Pitt. (2018). Taking a Learner-Centred Approach to Music Education: Pedagogical Pathways. 1st ed. Abingdon / New York: Routledge.

9. Komolov, O. (2020). Deglobalization and the "Great Stagnation. International Critical Thought, 10(3), 424-439 https://doi.org/10.1080/21598282.2020.1846582

10. Matselyukh, O. (2019). Fundamentals of organization and trends of academic professional music education in the Ukraine. E-Pedagogium, 19(2), 32-43 DOI: 10.5507/epd.2019.013

11. Nalyvaiko, O, Lykhoshvai, K. (2021). Quality of Professional Psychologist Training in Online Space. Educational Challenges, 26(2), 43-55.

12. Nalyvaiko, O., Vakulenko, A. \& Zemlin, U (2020). Features of forced quarantine distance learning. Scientific Notes of the Pedagogical Department, (47), 78-87. https://doi.org/10.26565/2074-8167-2020-47-09

13. Nalyvaiko, O., Khomenko, A., Vereshchak, D., \& Poliakov, D. (2021). Comparative Analysis of Distance Learning Systems in the United Arab Emirates and the United States of America. Educational Challenges, 26(1), 74-85. https://doi.org/10.34142/2709-7986.2021.26.1.07

14. Nogaj, A. A. (2020). Emotional Intelligence and Strategies for Coping With Stress Among Music School Students in the Context of Visual Art and General Education Students. Journal of Research in Music Education, 68(1), 78-96. https://doi.org/10.1177/0022429420901513

15. Ostapenko, L., Narozhna, N., \& Sinelnikova, V. (2020). Ways of renewal and modernization of art education in Ukraine. Image of the Modern Pedagogue, 3(192), 60-64. https://doi.org/10.33272/2522-9729-2020-3-60-64

16. Oxford Happiness Inventory. (2021) https://psycabi.net/testy/1076-obnovlennyi-oksfordskij-oprosnik-schastya-ohi-oxfordhappiness-inventory-i-pervonachalnyi-variant-metodiki-testy-dlya-diagnostiki-urovnya-schastya

17. Pakpour, A. H., M. D. Griffiths, and C. Y. Lin. (2020). Assessing Psychological Response to the COVID-19: The Fear of COVID-19 Scale and the COVID Stress Scales. International Journal of Mental Health and Addiction. doi:10.1007/s11469020-00334-9.

18. Payne, P. D., Lewis, W., \& McCaskill, F. (2020). Looking Within: An Investigation of Music Education Majors and Mental Health. Journal of Music Teacher Education, 29(3), 50-61. https://doi.org/10.1177/1057083720927748

19. Schiavio, A., Maes, P.-J., \& van der Schyff, D. (2021). The Dynamics of Musical Participation. Musicae Scientiae. https://doi.org/10.1177/1029864920988319

20. Tarkovska, D. et al., 2020. Study of the Music Market of Ukraine and Its Prospects in the International Economy https://issuu.com/soundbuzz/docs/study_of_the_music_market_of_ukraine_and_its_prosp

21. Thoma, M.V., La Marca, R., Brönnimann, R., Finkel, L., Ehlert, U., Nater, U.M. (2013) The Effect of Music on the Human Stress Response. PLoS ONE, 8(8), e70156. https://doi.org/10.1371/journal.pone.0070156

22. Thompson, W. F. (2009). Music, thought, and feeling. New York: Oxford University Press. 
23. Thornton, L. (2020). Music Education at a Distance. Journal of Music Teacher Education, 29(3), 3-6. https://doi.org/10.1177/1057083720928615

24. Yehuda, N. (2011). Music and stress. Journal of Adult Development, 18(2), 85-94.

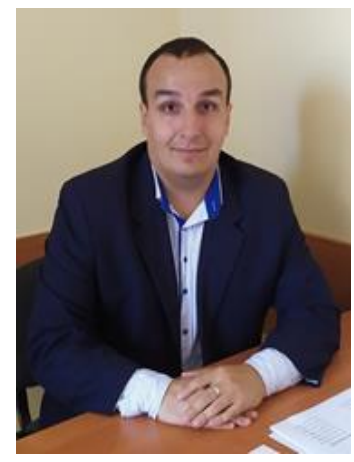

Наливайко Олексій Олексійович,

Кандидат педагогічних наук,

доцент кафедри педагогіки, заступник декана за наукової роботи факультету психології ,

Харківський національний університет імені В.Н. Каразіна,

Майдан Свободи, 6, Харків, 61022.

Тел. 0639586169. E-mail: nalyvaiko@karazin.ua

\section{Nalyvaiko Oleksii,}

Ph.D. in Pedagogy,

Associate Professor of Pedagogy Department, Deputy Dean for Research at the Faculty of

Psychology,

V. N. Karazin Kharkiv National University,

Maidan Svobody, 6, Kharkiv, Ukraine, 61022.

Tel. +380639586169 .E-mail: nalyvaiko@karazin.ua

ORCID: orcid.org/ 0000-0002-7094-1047

Researcher ID: AAW-3549-2020

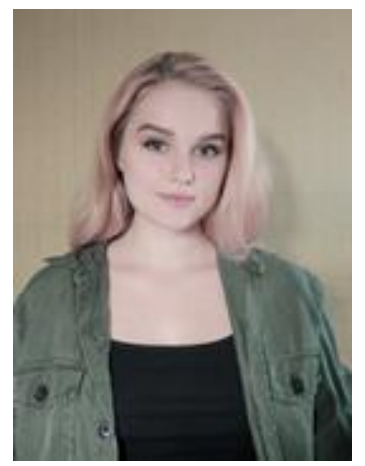

\section{Лихошвай Ксенія Юріївна,}

Студентка 4 курсу факультету психології ,

Харківський національний університет імені В.Н.Каразіна,

Майдан Свободи, 6, Харків, 61022.

Тел. +380507646605. E-mail: lykhoshvai.kseniia@gmail.com

Lykhoshvai Kseniia,

4th-year student of the School of Psychology,

V. N. Karazin Kharkiv National University,

Maidan Svobody, 6, Kharkiv, Ukraine, 61022.

Tel. +380507646605 . E-mail: lykhoshvai.kseniia@gmail.com

ORCID: orcid.org/0000-0002-4478-2767

\section{Citation (APA):}

Nalyvaiko O., Lykhoshvai K. (2021). Impact of higher music education on coping with stress during COVID-19. Engineering and Educational Technologies, 9 (3), 55-67. doi: https://doi.org/10.30929/2307-9770.2021.09.03.05

\section{Цитування (ДСТУ 8302:2015):}

Наливайко О. О., Лихошвай К. Ю. Вплив вищої музичної освіти на вміння впоратися зі стресом під час COVID-19 / Інженерні та освітні технології. 2021. Т. 9. № 3. С. 55-67. doi: https://doi.org/10.30929/2307-9770.2021.09.03.05

Обсяе статmі: сторінок-13; умовних друк. аркушів - 1,883. 